\title{
Food availability and accessibility in the local food distribution system of a low-income, urban community in Worcester, in the Western Cape province
}

\author{
Roos JA, MSc(Eng), Industry Analyst; Ruthven GA, BSc, BEng, HonsB(B\&A), MSc(UK), Lecturer \\ Department of Industrial Engineering, Stellenbosch University \\ Lombard MJ, NICUS Manager, Registered Dietitian \\ McLachlan MH, Food Security Initiative Leader and Director: Research and Information Division of Human Nutrition \\ Faculty of Medicine and Health Sciences, Stellenbosch University \\ Correspondence to: Joanita Roos, e-mail: joanitaroos@gmail.com \\ Keywords: food availability, food accessibility, community food security, food system
}

\section{Abstract}

Objectives: The objective was to understand the local food distribution system in Avian Park, with a focus on food availability and accessibility.

Study design: This was a quantitative food store survey that employed semi-structured interviews and focus group discussions.

Setting: The study was conducted in Avian Park, situated in the Breede Valley, in the Western Cape province.

Subjects: Thirteen spaza shops, three chain supermarkets, three street vendors, two butchers, two wholesalers, a community café and a small, independent supermarket randomly selected from the community were included. Food retail outlet managers and community residents were also included.

Outcome measures: The outcome measures were food prices, availability, and access and quality.

Results: The café stocked $56 \%$ of the surveyed food items, spaza shops $66 \%$ and the supermarket $69 \%$. Spaza shops stocked sweetened products, basic staples and processed food. A variety of vegetables was available at the cafe and supermarket, with less variety in the spaza shops. Processed and staple food was most expensive in the spaza shops, while fruit and vegetables were generally cheaper. Food prices were below the national average in all of the food categories, except for bread, cereals, grains, sweets and sugar. Interviews with shop owners indicated that fruit and vegetables were not kept because of spoilage, space limitations, storage issues and lack of transport. Focus group discussions with residents indicated a need for fruit, vegetables and meat outlets within walking distance.

Conclusion: Community food prices were not the main factor inhibiting food accessibility, but rather variety and quality.

๑ SAJCN

S Afr J Clin Nutr 2013;26(4):194-200

\section{Introduction}

Low-income communities or households living in informal settlements often struggle to obtain a nutritious diet. ${ }^{1}$ These marginalised communities consume mainly energy-dense, nutritionally inferior foods, and eat very little fruit and vegetables. ${ }^{2}$ Previous studies have shown that there is a connection between the ability to meet individual dietary needs and the local food environment. The availability and accessibility of food in retail outlets can influence dietary choices, and therefore the food security status of a community. ${ }^{3,4}$ This is particularly the case in urban and semi-urban communities, where access to retail outlets that sell a variety of affordable, nutritious food is a prerequisite for the adoption of a balanced diet. ${ }^{5,6}$

Research on the impact of the industrialisation and globalisation of the food system indicates that addressing food availability and access is not only a matter of agricultural production. It is important that attention is given to the entire food system. ${ }^{7}$ The present system is failing the urban poor, with market failures in both the formal and informal retail sectors. Furthermore, structural problems and an undesirable disparity exist between the two sectors, contributing to the prevalence of food insecurity in urban communities. The more food insecure households are, the more likely they are to depend on informal means of securing food. Therefore, the food system, in terms of the structure of food markets, and specifically the role of the informal food retail sector, must be considered when determining the factors that drive food insecurity. ${ }^{8}$

Rapid growth in the number of supermarkets globally has created fundamental changes in the food system, specifically with regard to food distribution. ${ }^{9}$ It is widely acknowledged that modern retailing is an important contributor to food security, as it ensures a regular supply of food and lower prices through efficient supply chains and procurement systems. ${ }^{9-11}$ However, supermarkets can also be 
a threat to food security and jeopardise the sustainability of agrifood systems. ${ }^{12}$ The dominant role that supermarkets play in the system empowers them to dictate food prices. ${ }^{13}$ It is predicted that the current trend in the food retail sector will continue, and that the sophisticated supermarket supply system will carry on dominating. ${ }^{9}$

Because of spatial planning during the apartheid era, currently, the urban poor do not have ready access to supermarkets. It is estimated that supermarkets have a $55 \%$ share of the national food retail market in South Africa, and the informal sector, 45\%. Therefore, the informal sector contributes significantly to the economy and to community food security. ${ }^{14}$

Small general dealers, spaza shops and street vendors usually comprise the food retail environment in low-income or rural communities. ${ }^{8,10}$ Greenberg $^{14}$ argues that these markets are important outlets for food distribution to lower-income groups as they bring food retail outlets closer to the consumer. The informal market remains the main source of food for the poor. ${ }^{8}$

These informal retail outlets cannot match economies of scale in terms of price reductions because of the efficiency of operation of the supermarkets. ${ }^{11}$ Food prices tend to be higher in the local shops than in the supermarkets, and when compared with average national food prices. ${ }^{10,11}$ According to Ligthel, ${ }^{15}$ small retailers are becoming a permanent phenomenon on the South African economic scene. Food store surveys conducted in the USA, Canada and the UK found that smaller, independent food retail outlets (corner shops) stocked a smaller variety of food items compared to the supermarkets in those countries. Available food items in smaller stores were mostly processed, carbohydrate-based foods, with minimal fresh produce. The prices were also higher than those of the supermarkets. ${ }^{5,16,17}$ Cummings concluded that the type of retail outlet is the main predictor of food price and availability. ${ }^{18}$

Furthermore, Minten and Reardon, ${ }^{19}$ who conducted studies on the quality of food in retail outlets in Africa, reported a stable, predictable pattern whereby supermarkets offered better prices, availability and quality food products than traditional markets. They found that this was also true for South Africa.

Research conducted in the rural areas of the Eastern Cape found that prices for processed food, bread and sugar, in the spaza shops were higher than national average prices, with a mark-up for maize meal as high as $40 \%$. The higher prices in local shops were owing to transportation and distribution costs. Local shop owners procured stock from the same supermarkets where consumers with access shopped. Spaza shop owners have extremely low financial liquidity and do not buy in bulk. Therefore, wholesalers do not provide discounts. Households with members who shopped at supermarkets generally had a higher income than those using the local stores. Consumers from the poorest households were attracted to the quality, price and variety of products available in the supermarkets, but were marginalised in their access to these supermarketassociated benefits. ${ }^{10}$
A study conducted in the rural towns of the Western Cape found that supermarkets stocked healthy food at competitive prices, compared to small stores with a limited selection of healthy food. Although residents could travel to the larger towns to shop at supermarkets, there were still storage and transportation limitations. ${ }^{2}$

Therefore, low-income households are vulnerable to the food system in which they operate. The food system refers to the chain of activities that connect primary producers, manufacturers, processors, wholesalers, retailers and consumers. ${ }^{20}$ More specifically, community food security depends on the availability, quality and affordability of a variety of items sold through retail or any other food source. A community may be considered to be food insecure if there are inadequate nutritional resources, and/or which are not accessible to all community members. Thus, quantity and affordability of food are pivotal issues in the matter of food security in South Africa. ${ }^{21}$

To date, little has been carried out to strengthen the informal food retail sector. However, it has been acknowledged that the important role of the informal market must not be overlooked, and that connections between the formal and the informal food sectors must be strengthened. ${ }^{7}$

The aim of this study was to determine food availability and accessibility within the current local food distribution system of Avian Park, Worcester, in the Western Cape province. This research initiative, conducted in partnership with the Department of Industrial Engineering, was part of the Community Nutrition Security Research Project (CNSP) of the Division of Human Nutrition, Stellenbosch University. Ethical approval was obtained from the Stellenbosch University Ethics Committee (N10/11/368). Participants provided informed written consent.

\section{Method}

Data were collected using three different methods: food store surveys, in-depth interviews with the owners and managers of retail outlets, and focus group discussions.

\section{Food store surveys}

Avian Park is situated in the Breede Valley in the Western Cape, where there are formal and informal housing sections. There are approximately 10000 residents, of whom $21 \%$ are unemployed. ${ }^{22}$

The retail environment of Avian Park mainly consists of spaza shops that are spread throughout the community. A spaza shop is defined as a shop or business operating in a section of an occupied residential home, or in any other structure on a stand in a formal or informal township which is used for residential purposes, and where people live permanently. There are 46 spaza shops within Avian Park, with one spaza shop on every street, except in the more informal and poorer neighbourhoods in the community, where these outlets are fewer in number. Apart from the spaza shops, Avian Park has an independent supermarket at the centre of the community, and a café on its outskirts. A variety of supermarkets and street vendors sell fresh fruit and vegetables, and there are also butcheries in Worcester, 4-5 km from Avian Park. 
An area map of the community was obtained from the municipality. All of the streets were numbered. Thirteen streets were randomly selected. One spaza shop from every randomly selected street was included in the study. The starting point of each street was selected at random to ensure that these differed from street to street. In cases where there were no spaza shops in the street, another street was selected at random, and a spaza shop in that street was approached for participation. Participation was determined through random selection if more than one spaza shop was situated in a street.

A quantitative food store survey, developed by the United States Department of Agriculture (USDA), ${ }^{21}$ was adapted for applicability to the South African landscape. The survey comprised a list of 70 commonly consumed food items, identified during a food procurement study conducted by the CNSP, as well as an expert committee comprising dietitians from Stellenbosch University with an in-depth knowledge of food and dishes consumed in Avian Park. The food in the list included fresh fruit and vegetables (only inseason fruit and vegetables were included), bread, cereals and other grains, dairy products, meat and meat alternatives, fats and oils, and sugar and sweets.

Availability, price and the type of outlet for each food item was recorded. The prices for fresh fruit and vegetables, and meat and meat alternatives, were collected in Rand/ $\mathrm{kg}$, and the produce was weighed in cases where this was not indicated. The food price and packaging size was recorded for the other food groups, and during the analysis, the Rand $/ \mathrm{kg}$ was determined for all of the food items. The difference in the pricing of specific brands and packaging sizes for food items was taken into account by comparing identical brands and sizes only during the study analysis.

Competitive pricing of food items was determined using three price analyses. The first compared the prices of the different food categories across the different food retail outlets. Single-factor analysis of variance (ANOVA) comparisons were performed to determine whether or not the means of the food prices across the different food retail outlets were equal. Prices of selected food items were also compared and specific comparisons made between the informal and formal food retail sector. The second price analysis calculated the mark up of the food items in the informal food retail sector. The third analysis compared the prices in different food retail outlets with average national retail prices. A nutritious food basket was used as a survey tool to measure the cost of basic healthy eating across the different food retail outlets. The national average prices ${ }^{23}$ were used as benchmark prices. The food basket consisted of a quantity of food purchased by an average South African adult in a month determined by the National Agricultural Marketing Council (NAMC). It represented a balanced diet and included 23 food items from all of the food categories (Table I). ${ }^{24}$

Finally, the cost of the food basket was also compared to household income figures derived from a study carried out in Avian Park by the Department of Sociology and Social Anthropology, Stellenbosch University, in 2011.25 The mark up of the selected items was determined by calculating the margin between the wholesale price
Table I: Food items included in the National Agricultural Marketing Council food basket

\begin{tabular}{|c|c|}
\hline Food item & Weight \\
\hline Apples & $1 \mathrm{~kg}$ \\
\hline Bananas & $1 \mathrm{~kg}$ \\
\hline Beans (dried) & $500 \mathrm{~g}$ \\
\hline Beans (canned) & $410 \mathrm{~g}$ \\
\hline Bread (white) & $700 \mathrm{~g}$ \\
\hline Cabbage & 1 head \\
\hline Cake flour & $2.5 \mathrm{~kg}$ \\
\hline Chicken pieces & $1 \mathrm{~kg}$ \\
\hline Coffee & $750 \mathrm{~g}$ \\
\hline Eggs & 1.5 dozen \\
\hline Maize meal & $2.5 \mathrm{~kg}$ \\
\hline Margarine & $500 \mathrm{~g}$ \\
\hline Milk & 11 \\
\hline Onions & $1 \mathrm{~kg}$ \\
\hline Orange & $1 \mathrm{~kg}$ \\
\hline Peanut butter & $410 \mathrm{~g}$ \\
\hline Pilchards (canned) & $425 \mathrm{~g}$ \\
\hline Potatoes & $1 \mathrm{~kg}$ \\
\hline Rice & $2 \mathrm{~kg}$ \\
\hline Samp & $2.5 \mathrm{~kg}$ \\
\hline Sugar & $2.5 \mathrm{~kg}$ \\
\hline Sunflower oil & $750 \mathrm{ml}$ \\
\hline Tea & $62.5 \mathrm{~g}$ \\
\hline
\end{tabular}

and the retail price in the local shops, and then expressed as a percentage.

\section{In-depth interviews with the owners and managers of retail outlets}

In order to gain a better understanding of the functioning of the current distribution system in Avian Park, interviews with the owners and managers of the different food retail outlets were undertaken. Twenty-five interviews were conducted in Afrikaans or English. Experienced fieldworkers conducted the interviews in isiXhosa when required. Two women residing in the community worked as fieldworkers to establish a platform of trust with the interviewees. Each interview took 40 minutes to conduct. Notes were taken by the researcher and field workers interchangeably. Specific questions with regard to the food distribution system were based on a national study that was carried out by the Bureau of Market Research, University of South Africa. Questions were asked about the retail outlet facility, purchasing procedures and local food distribution. ${ }^{26}$

The wholesalers included in the study sample were identified through semi-structured interviews with retail owners. Owners sourced their stock from two wholesalers. 


\section{Focus group discussions}

Focus group discussions were conducted to obtain insight into the personal views, cultural practices, beliefs and experiences of the community residents with regard to the availability and accessibility of food in the community. Perceptions on food prices and information concerning grants and pensions were also obtained through the focus group discussions. The supermarkets, butchers and street vendors that were visited most frequently in town were established through the focus group discussions and included in the study sample.

Discussions were carried out according to the guidelines in the USDA Community food security assessment toolkit and adapted for the South African context. These discussions were conducted at a local clinic that was safe and easily accessible, e.g. close to public transport and taxi routes. The discussions lasted approximately 30 minutes. Participants were recruited using snowball sampling. A maximum of eight people participated in a single focus group discussion. The focus group discussions were conducted and notes were taken by trained, experienced fieldworkers who resided in the community. The discussions were also voice recorded and transcribed by the fieldworkers.

\section{Results}

The overall study sample included 13 spaza shops, three chain supermarkets, three street vendors, two butchers, two wholesalers, the community café and a small, independent supermarket.

\section{Food store surveys}

\section{Variety of food in the community}

All of the included spaza shops in the study stocked carbonated drinks, sweets, chocolates and basic staple and processed food items, such as rice, maize meal, long-life milk and tinned food. Onions and potatoes were stocked in $58 \%$ and $67 \%$ of the spaza shops, respectively. A frequency count showed that only $17 \%$ of the spaza shops stocked apples, and $25 \%$ bananas. None of them sold carrots or green vegetables. Tomatoes were available in only $17 \%$ of spaza shops at the time of the survey. The café in the community stocked just over half (56\%) of the food items surveyed. Spaza shops sold $66 \%$ of the items available, i.e. $3 \%$ less than the $69 \%$ of the items stocked by the small supermarket.

A variety of vegetables could be purchased from the café and the small supermarket, including butternut, green beans, cucumber and cabbage. The small supermarket in the centre of the community sold chicken pieces, chicken chunks, offal and sausage. All of the items that were included in the survey were available at the supermarkets in town. Street vendors sold $78 \%$ of the fruit and vegetables.

\section{Price comparisons across the different retail outlets}

The average retail prices of the five food categories were compared across the different food retail outlets (Figure 1).
It is important to note that only the food items that were available from all of the different retail outlets in each food category were included in this analysis. Using ANOVA tests, the price differences for fresh fruit and vegetables, and meat and meat alternatives, varied significantly from store type. Fresh fruit and vegetables were generally less expensive in the spaza shops, but meat and meat alternatives were priced higher in these shops. Prices for chicken chunks and pieces were $50 \%$ and $29 \%$ respectively, costing more at the spaza shops than when bought in town. The small supermarket in the community charged higher prices than the supermarket located in Worcester, 4-5 km from Avian Park, for both chicken products.

The average price of food items most frequently procured within the community were compared across the different food retail outlets (Figure 2). Prices for selected food items were competitive. Five of the selected items had similar prices.

Retail prices for tea were highest in the spaza shops. Figure 2 reveals that in general, beverages were expensive at the spaza shops and at the café in the community. Generally, products with a longer shelf life were cheapest in the community supermarket, while those with a shorter shelf life, e.g. eggs, were more expensive. Overall, prices were cheaper at the supermarket in town than at any outlet in the community.

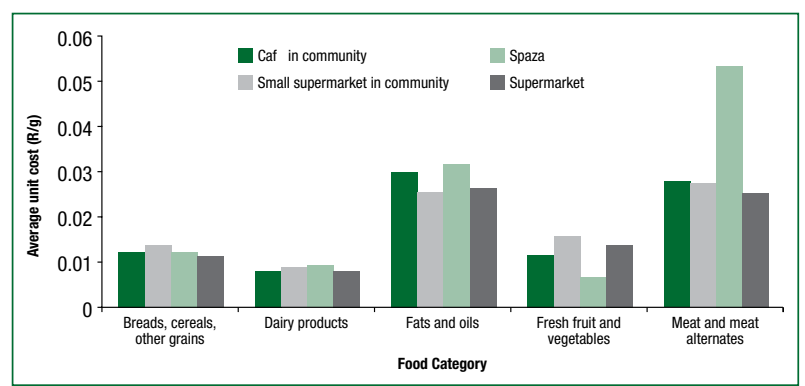

Figure 1: Price comparisons of the different food categories

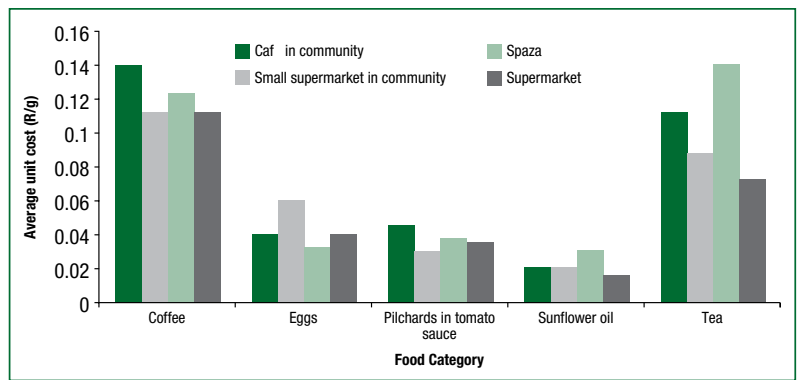

Figure 2: Price comparisons of frequently procured food items

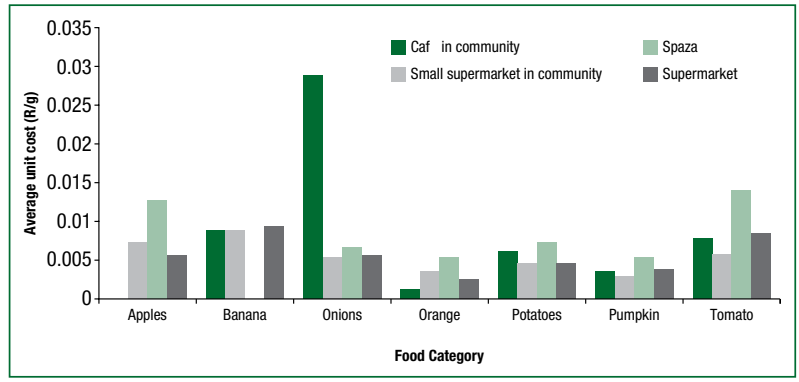

Figure 3: Price comparisons of fresh fruit and vegetables 
Prices for fresh produce varied more distinctly among different outlets than those for processed food items. Selected produce prices for available fresh fruit and vegetables in the café, the spaza shops and supermarkets, and from street vendors were compared (Figure 3 ).

Supermarkets asked higher prices for selected fresh fruit and vegetables than the informal retail sector, with the exception of bananas. Prices among different food items varied in the informal retail sector. Higher prices for apples, oranges and potatoes were charged by the spaza shops, compared to those asked by the street vendors in the nearby town (Figure 3).

\section{The mark up on food items in the informal retail sector}

The average mark up for processed items in the spaza shops varied among food items, ranging from $9 \%$ for bread, to $163 \%$ for tea. Processed food was defined as food items that underwent deliberate changes to their natural state before being made available for consumption. ${ }^{4}$ The mark ups for chips $(116 \%)$, pilchards in tomato sauce $(90 \%)$, samp and beans $(82 \%)$ and rice $(74 \%)$ were also high. These are among the food items that contributed the most to the spaza shops' monthly turnover.

The average mark up by the spaza shops and vendors varied depending on the different produce, ranging from $9 \%$ for tomatoes to $202 \%$ for apples in the spaza shops, and from $13 \%$ for sweet potatoes to $117 \%$ for oranges from the vendors. On average, there was a higher mark up on fresh fruit and vegetables by the spaza shops than that by the street vendors. Yet the prices for fresh fruit and vegetables in the informal food retail sector were still reasonably competitive with the chain supermarkets.

\section{Price comparison with national average retail prices}

Food prices in Avian Park and the surrounding areas were below the national averages for all food categories, except for bread, cereals and other grains, and sweets and sugar (Figure 4).

Fresh fruit and vegetable prices are noticeably lower than the national average prices. The Consumer Price Index for urban consumers was derived from the average South African prices determined by the NAMC. ${ }^{23}$

A comparison of different food baskets were conducted to further analyse the local food distribution system.

Basket A was the cost of a basket of food items purchased by an average South African adult in a month. The prices were derived from the average South African prices determined by the NAMC. ${ }^{23}$

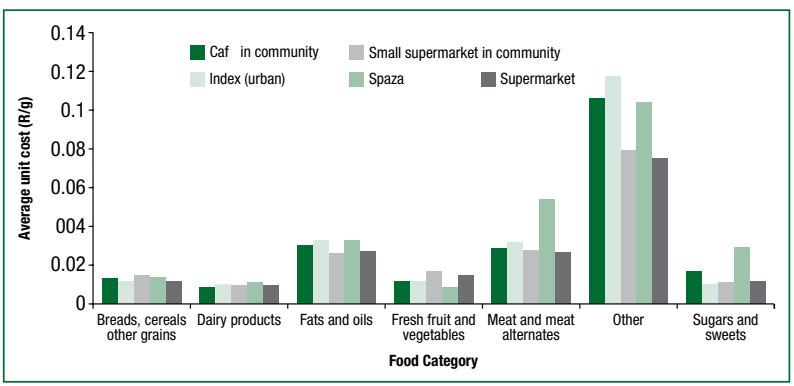

Figure 4: Food category prices compared to the national average
Basket B was the cost of the identical food items in basket $A$. The lowest food prices of available food items in Avian Park were utilised to determine the cost of the basket. Basket $C$ was the cost of the identical food items in basket $A$. The lowest food prices of food items available in both Avian Park and the retail outlets in town were utilised to determine the cost of the basket.

The total cost of obtaining the NAMC food basket (basket A) was R353. This was used as a benchmark and compared to baskets B and $C$ (Table II). The cost of market basket $C$ was R59, i.e. $17 \%$ less than the national average food prices. Residents would have to pay R35 (11\%) more if they only had access to outlets within Avain Park and were unable to go to the supermarkets in town or buy from a street vendor. The market basket also costed R37 more if only spaza shop prices were compared to the chain supermarket prices. In either case, overall, the residents would still be pay less than the national average for their food items. Limited food access was a context-specific problem in the community, because of the limited type of food items that were available in the immediate food retail environment of Avian Park.

Table II: National Agricultural Marketing Council market basket comparison

\begin{tabular}{|l|c|}
\hline Market basket & Price (R) \\
\hline Basket A & 353 \\
\hline Basket B & 329 \\
\hline Basket C & 294 \\
\hline
\end{tabular}

Calculations in Table IV reveal that $20 \%$ of households in Avian Park would not be able to afford a basket of food if they were to only procure food from the immediate food retail environment (basket B). If the cost of basket $C$ was taken into account, the same proportion of the community would have to spend $93 \%$ of their monthly income to meet their basic dietary needs.

Half of the households in Avian Park would have to spend 33\% and $29 \%$ of their monthly income to obtain baskets B and C, respectively. The remaining $30 \%$ of households would have to spend $22 \%$ and $20 \%$ of their monthly income to obtain food baskets B and C.

Table IV: The cost of food baskets B and C, compared to household income

\begin{tabular}{|l|c|c|c|}
\hline $\begin{array}{l}\text { Per capita } \\
\text { income (R/ } \\
\text { month) }\end{array}$ & $\begin{array}{c}\text { Proportion of } \\
\text { households in } \\
\text { the community } \\
\text { with specific } \\
\text { per capita } \\
\text { income }\end{array}$ & $\begin{array}{c}\% \text { of income } \\
\text { spent on } \\
\text { purchasing } \\
\text { basket B }\end{array}$ & $\begin{array}{c}\% \text { of income } \\
\text { spent on } \\
\text { purchasing } \\
\text { basket C }\end{array}$ \\
\hline 316 & $20 \%$ & N/A & $93 \%$ \\
\hline 1000 & $50 \%$ & $33 \%$ & $29 \%$ \\
\hline 1500 & $30 \%$ & $22 \%$ & $20 \%$ \\
\hline
\end{tabular}

N/A: not applicable

\section{In-depth interviews with the owners and managers of the retail outlets}

The interviews with spaza shops owners revealed that they did not carry a variety of fruit and vegetables because of spoilage, space 
limitations, storage issues and the lack of transport. On average, $50 \%$ of the spaza shops sold meat, but it was predominantly chicken chunks or soup packs.

Furthermore, of retail outlets included in the study, only $16 \%$ (two of the spaza shops and two butchers) sold local food. Local food refers to food that is produced and distributed within the borders of the Breede Valley Municipality. This includes Rawsonville, De Doorns and Touwsrivier.

\section{Focus group discussions}

\section{Food accessibility}

According to women in the community, there was a need for a butcher and more fruit and vegetable retail outlets within walking distance of the households. Discussions revealed that at times, the meat that was purchased from the spaza shops was rotten.

\section{Physical accessibility of the retail outlets}

The residents of Avian Park had relatively easy access to the spaza shops as they are distributed throughout Avian Park. However, it was more difficult to access the variety of retail outlets that were available in town. The nearest chain supermarket was 4-5 km away. Most of the residents did not own their own vehicles. Walking was reported to be dangerous and taxi fees considered unaffordable. It was further revealed from the food discussion groups that the availability of credit transactions at local outlets served as an incentive to shops within the community.

\section{Food prices}

Food was perceived to be expensive. Participants reported that their budgets did not allow them to purchase a variety of healthy food. Households that were dependent on government grants or pensions were especially limited with regard to access to food in terms of affordability.

\section{Discussion}

The research findings were used to characterise the food retail environment in Avian Park.

A chain supermarket is not situated in Avian Park. The food retail environment predominantly consists of spaza shops. The residents are within walking distance of the café and a small supermarket situated within the community. It was found that food prices in Avian Park and surrounding areas were below the national average in all food categories, except for bread, cereals and other grains, and sweets and sugar. Therefore, the problem of food access in terms of affordability was more context specific, and was not a regional problem, as it is in the rural areas of the Eastern Cape. ${ }^{10}$

Three main factors influenced the availability and accessibility of nutritious food in the community, namely limited access to the food retail outlets in town, limited variety, the low quality of available food in the retail outlets within the community and lack of local food distribution.
Modern retailing is an important contributor to food security. Research clearly shows that constrained access to retail hubs is at the core of a community's inability to benefit from the existing competitive supermarket system. Generally the most competitive prices for processed and staple food items were in the supermarkets in town. Community residents did not have a variety of fresh fruit, vegetables, nor fresh meat, available in their immediate food retail environment.

In the light of the connection between the local food environment and the dietary choices of a community, the residents of Avian Park were limited in their access to a variety of nutritious food at the best prices.

Given the high availability of food items at the supermarkets and from the street vendors in town, it seems that the main disadvantage pertaining to the variety and quality of food items was having to rely on the immediate food retail environment within the community.

A less diverse range of food of lower quality was available to the poorest residents in the community who did not have access to transport. The spaza shops stocked mostly potatoes, onions and bananas in the fresh fruit and vegetable category, and the mark ups were high. However, the prices were still reasonably competitive when compared to those in the chain supermarkets. This is unexpected if a comparison is made with the findings in rural towns in the Western Cape, whereby the best prices were predominantly found in supermarkets. ${ }^{2}$ The café and the small supermarket in the community stocked a variety of fresh produce for the residents and sold butternut, green beans, cucumber and cabbage. However, it was found that the prices for these items were higher than those charged by the street vendors in town.

We are in agreement with Battersby ${ }^{8}$ and Greenberg ${ }^{14}$ that the informal food retail sector must be considered when determining factors that drive food insecurity. The inefficient working of the spaza shops value chain was identified in Avian Park as an area that needs attention. Improving healthy food availability in the spaza shops could be an effective way of enhancing the food retail environment in Avian Park. Another strategy could be to organise the spaza shops into a collective buying force in the form of business clusters. Co-operative buying schemes would enable owners to aggregate their purchasing power, and thus obtain bulk buying benefits and discounts. These strategies and the distribution of local food could ensure greater sustainable food availability and accessibility for the community.

The lack of local food distribution is considered to be a significant challenge from a nutrition point of view and from a food system perspective. Given that Avian Park is situated in a fruit-producing area, the implementation of effective distribution systems could ensure that low-cost, high-quality produce reaches the community in support of the overall food security status of the community.

\section{Conclusion}

Food prices are not the main factor inhibiting food accessibility in Avian Park. The problem is also the lack of variety and poor quality of food that is available in the food retail environment. 


\section{References}

1. Schonfeldt HC, Gibson N, Vermeulen H. The possible impact of inflation on nutritionally vulnerable households in a developing country using South Africa as a case study. Nutrition Bulletin. 2010;35:254-267.

2. Temple NJ, Steyn NP. The cost of a healthy diet: a South African Perspective. Nutrition. 2011;27(5):505-508.

3. Krukowski RA, West DS, Harvey-Berino J, Prewitt TE. Neighborhood impact on healthy food availability and pricing in food stores. J Community Health. 2010;35(3):315-320.

4. Scheier LM. What is the hunger-obesity paradox? Am Diet Assc. 2005;105(6):883-886.

5. AzumaAM, Gilliland S, Vallianatos M, Gottlieb R. Food access, availability and affordability in 3 Los Angeles communities. Prev Chronic Dis. 2010;7(2):1-9.

6. Hamm WM, Bellows AC. Community food security: background and future directions. $J$ Nutr Educ Behav. 2003;35(1):37-43.

7. Eide WB, Kracht U. Food and human rights in development. Antwerpen: Intersentia; 2005

8. Battersby J. Urban food insecurity in Cape Town, South Africa: an alternative approach to food access. Development Southern Africa. 2011;28(4):545-61.

9. Weatherspoon D, Neven D, Katjiuongua HB, et al. Battle of the supermarket supply chains in sub-Saharan Africa: challenges and opportunities for agrifood suppliers. United Nations; 2004.

10. D' Haese M, Van Huylenbroeck G. The rise of supermarkets and changing expenditure patterns of poor rural households case study in the Transkei area, South Africa. Food Policy. 2005;30:97-113.

11. Reardon T, Hopkins $R$. The supermarket revolution in developing countries: policies to address emergin tensions among supermarkets, suppliers and traditional retailers. European Journal of Research Development. 2006;18(4):522-545.

12. Weatherspoon DD, Reardon T. The rise of supermarkets in Africa: implications for agrifood systems and the rural poor. Development Policy Review. 2003;21(3):335-355.

13. Pimbert M. Towards food sovereignty: reclaiming autonomous food systems. London: International Institute for Environment and Development; 2008.
14. Greenberg S. Contesting the food system in South Africa: issues and opportunities Belville: Institute for Poverty, Land and Agrarian Studies (PLAAS); 2010.

15. Ligthelm AA. Profile of informal microenterprises in the retail sector of South Africa. San Antonio Business Journal. 2004; 8(1):39-52.

16. Latham J, Moffat J. Determinants of variation in food cost and availability in two socioeconomically contrasting neighbourhoods of Hamilton,Ontario, Canada. Health Place. 2007;13(1):273-287.

17. Liese $A D$, Weis $K E$, Pluto $D$, Food store types, availability, and cost of foods in a rural environment. J Am Diet Assoc. 2007;107(11):1916-1923.

18. Cummins S, Macintyre S. A systematic study of an urban foodscape: the price and availability of food in greater Glasgow. Urban Studies. 2002;39(11):2115-2130.

19. Minten B, Reardon T. Food prices, quality and quality's pricing in supermarkets versus traditional markets in developing countries. Appl Econ Perspect Pol. 2008;30(3):480-490

20. Tansey G, Worsley T. The food system. London: Earthscan; 1995.

21. Cohen B. Community food security assessment toolkit. Food assistance and nutrition research program. United States Department of Agriculture; 2002.

22. Breede Valley Municipality. Integreated development plan 2007-2011. Breede Valley Muncipality; 2007

23. Food price monitor, August 2011. Pretoria: National Agricultural Marketing Council; 2011.

24. Jacobs PT. The status of household food security targets in South Africa. Agrekon. 2009;48(4):410-433

25. Heinecken L, Vorster J, du Plessis J. Socio-economic and social capital assessment of Avian Park residents, Worcester. Stellenbosch: Department of Sociology and Social Anthropology, Stellenbosch University; 2010.

26. Ligthelm AA. Characteristics of spaza retailers. Evidence from a national survey. Pretoria: Bureau of Market Research; 2002. 